\title{
Aktivitas Hepatoprotektif Ekstrak Kunyit (Curcuma domestica Val.) dan Ekstrak Meniran (Phyllantus niruri Linn.) Pada Tikus yang Diinduksi Parasetamol Kajian Histopatologi Liver
}

\section{Hepatoprotective activity of Curcuma domestica Extract And Phyllantus niruri Extract on Histopathology Rat Induced by Paracetamol}

\author{
Agil Novianto $^{1}$, Arief Nurrochmad ${ }^{2}$, Ika Puspitasari ${ }^{2}$ \\ 1) Universitas Gadjah Mada \\ 2) Departemen Farmakologi dan Toksikologi, Farmasi Universitas Gadjah Mada
}

\begin{abstract}
Intisari
Curcuma domestica dan Phyllanthus niruri adalah dua tanaman yang telah terbukti memiliki efek hepatoprotektif. Penelitian ini dilakukan untuk mengetahui studi mekanisme hepatoprotektif dari kombinasi ekstrak Curcuma domestica dan Phyllanthus niruri dengan hewan yang diinduksi parasetamol. Hewan dibagi menjadi 8 kelompok secara acak masingmasing 5 tikus. Kelompok yang normal adalah aquadest, kelompok negatif (Parasetamol) adalah CMC Na 0,5\%, kelompok positif diberi silimarin dengan dosis $100 \mathrm{mg} / \mathrm{kg}$ kelompok Curcuma domestica dengan dosis 100 $\mathrm{mg} / \mathrm{kg}$, kelompok Phyllanthus niruri dengan $200 \mathrm{mg} / \mathrm{kg}$ BB serta kombinasi I-III dengan Curcuma domestica dan Phyllanthus niruri perbandingan ekstrak masing-masing 75: 50; 50: 100; dan 25: $150 \mathrm{mg} / \mathrm{kg}$ di BW. Persiapan uji diberikan selama 7 hari. Pada hari ke-7, semua kelompok kecuali yang normal diinduksi dengan parasetamol tunggal dose $2.5 \mathrm{~g} / \mathrm{kg}$ untuk peroral 30 menit setelah pemberian persiapan tes. Aktivitas hepatoprotektif dianalisis menggunakan histopatologi hati. Hasil penelitian menunjukkan bahwa kombinasi I dapat menghambat nekrosis hati dan memberikan aktivitas hepatoprotektif baik dibandingkan dengan dosis tunggal dengan Curcuma domestica optimal dan ekstrak Phyllanthus niruri dosis 75 dan $50 \mathrm{mg} / \mathrm{kg}$
\end{abstract}

\section{Abstract}

Curcuma domestica and Phyllanthus niruri was two plants which has been shown to have an effect hepatoprotective. This research was conducted to determine mechanism study of hepatoprotective combination of Curcuma domestica and Phyllanthus niruri extract to animals induced by paracetamol. Animals devide into 8 groups in random order of 5 each rats. Normal groups were give aquadest, negative groups (Paracetamol) were give CMC Na 0,5\%, positive goups were give silimarin with dose 100 $\mathrm{mg} / \mathrm{kg}$, Curcuma domestica groups with a dose of $100 \mathrm{mg} / \mathrm{kg}$, Phyllanthus niruri groups with $200 \mathrm{mg} / \mathrm{kg}$ BW as well as a combination of I-III with Curcuma domestica and Phyllanthus niruri extract comparison of each of 75: 50; 50: 100; and 25: $150 \mathrm{mg} / \mathrm{kg}$ in BW. Test preparations are given for 7 days. On day 7 , all groups except normal induced with paracetamol single dose $2.5 \mathrm{~g} / \mathrm{kg}$ for peroral 30 minutes after administering the test preparations. Hepatoprotective activity were analyzed using liver 
histopathology. The results showed that the combination I can inhibited liver necrosis and gives better hepatoprotective activity comparable with single dose with optimal Curcuma domestica and Phyllanthus niruri extract dose of 75 and $50 \mathrm{mg} / \mathrm{kg}$.

Keywords: Curcuma domestica, Phyllanthus niruri hepatoprotective, hystopatology

\section{PENDAHULUAN}

Penyakit hati sampai saat ini masih menjadi problem kesehatan yang serius. Kerusakan hati dapat terjadi karena infeksi, virus, penggunaan obat, dan lingkungan (Singh, 2001). Parasetamol merupakan obat dengan efek analgetik dan antipiretik yang aman digunakan dalam pemakaian pada dosis dibawah 4,0 $\mathrm{g} /$ hari (Clark et al., 2012). Penggunaan parasetamol dalam jumlah yang berlebih (15 gram/hari) mampu menyebakan kerusakan pada hati yang ditandai dengan terbetuknya nekrosis (Sabate et al., 2011; Clark et al., 2012). Parasetamol mengalami proses metabolisme oleh enzim sitokrom P450 menjadi metabolit reaktif yang dikenal dengan $\mathrm{N}$-acetyl-p-benzoquinonemine (NAPQI). NAPQI mampu berinteraksi secara kovalen dengan makromolekul hati pada bagian sistein dan mengakibatkan terjadinya oksidasi lipid dan menyebabkan kerusakan pada liver (Setty, 2007). Terjadinya nekrosis pada hati oleh pemberian parasetamol ditandai dengan naiknya kadar serum glutamate pyrwvate transaminase (SGPT), serum glutamate oxaloacetat transaminase (SGOT), serum alkaline phosphatase (ALP), billirubin, dan total protein (Hinson et al., 2010) dan penurunan aktivitas superoxide dismutase (SOD), catalase (CAT), glutathione(GSH).

Kunyit memiliki aktivitas hepatoprotektif terhadap beberapa senyawa hepatotoksin sepertiparasetamol, galatosamine, $\mathrm{CCl}_{4}$, thioacetamide (Kiso et al., 1983; Park et al., 2000; Salama et al., 2013; Donatus et al., 1990; Goenarwo dkk., 2009). Meniran (Phyllanthus niruri Linn) memiliki efek hepatoprotektif terhadap senyawa hepatotoksin seperti parasetamol, $\mathrm{CCl}_{4}$ (Harish and Shivanandappa, 2006; Manjrekar et al., 2008). Meniran terbukti mampu mengurangi terjadinya stres oksidatif dan kerusakan liver akibat pemberian alkohol (Rajagopalan et al., 2010).

Sejauh ini belum diketahui efek penggunaan kombinasi ekstrak kunyit dan meniran terhadap senyawa hepatotoksin parasetamol. Perlunya dilakukan penelitian untuk mengetahui aktivitas hepatoprotektive kombinasi ekstrak kunyit dan meniran pada hewan uji yang diinduksi parasetamol dengan melihat parameter histopatologi liver.

\section{METODE PENELITIAN}

Alat

Alat yang digunakan dalam penelitian meliputi, Analisis KLT: KLT, UV cabinet, Penetapan kadar ekstrak : spektrofotometer, TLC densitometer. Analisis kadar serum: micro vitalab. Analisis parameter stress oksidatif: Spektrofotometer,

Bahan

Ekstrak Kunyit (Gama Herbal) dan Ekstrak Meniran (Gama Herbal). Hewan uji tikus jantan galur Wistar berat 150200g, dengan umur 2-3 bulan (Laboratorium Farmakologi dan Toksikologi Fakultas Farmasi UGM Yogyakarta). Parasetamol 500 mg (Kimia Farma), Silimarin (Aldrich). Bahan untuk KLT standar kurkuminoid, kloroform p.a, etanol p.a, metanol p.a (sigma), asam borat (Brataco), standar kuersetin, $\mathrm{AlCl}_{3}$ (Brataco) etil asetat, natrium sitrat, asam 
asetat (sigma). Analisa histopatologi dengan menggunakan pengecatan Hematoksilin Eosin

\section{Pembuatan Ekstrak}

Kunyit sebanyak $2 \mathrm{~kg}$ didestilasi untuk menghilangkan minyak atsiri, setelah itu dikeringkan dan diserbuk kemudian dilakukan ekstraksi dengan menggunakan metode maserasi dengan solven etanol $96 \%$ perbandingan 1:7. Herba meniran sebanyak $2 \mathrm{~kg}$ dilakukan ekstraksi dengan menggunakan metode maserasi solven etanol $70 \quad \%$ perbandingan 1:7.

\section{Analisis Kualitatif}

Ekstrak kunyit dan meniran ditetapkan kadar air dengan metode destilasi dan ditentukan kadar abu total serta kadar abu tidak larut asam.. Profil KLT dilakukan dengan fase gerak kloroform metanol (95:5), fase diam silica gel F254, sebagai pembanding digunakan kurkumin $0,1 \%$ dalam etanol. Deteksi menggunakan UV254 dan digunakan pereaksi semprot asam borat methanol (Depkes RI, 2008). Uji KLT terhadap ekstrak meniran dengan menggunakan fase gerak butanol: asam asetat: air (4:1:5), fase diam silica gel F254, sebagai pembanding digunakan kuersetin 0,5\% dalam metanol. Deteksi dilakukan dalam UV 254, UV366 dan pereaksi semprot $\mathrm{AlCl}_{3} 5 \%$ dalam metanol (Depkes RI, 2008).

\section{Analisis Kuantitatif}

Penetapan kadar Kurkuminoid dalam ekstrak kunyit dilakukan dengan metode KLT Densitometri. Fase gerak digunakan kloroform metanol (95:5). Setelah dielusi plat selanjutnya dikeringkan dan dilakukan scanning dengan Camag TLC pada panjang gelombang 425 nm (Pothitirat \& Gritsanapan 2005). Analisis total flavonoid dalam ekstrak meniran menggunakan metode Chang et al. (2002) dihitung berdasarkan quercetin equivalent. Analisis total flavonoid ekstrak meniran diukur absorbansinya pada 440 nm (Suhad et al., 2008).

\section{Uji aktivitas hepatoprotektif}

Hewan uji dibagi menjadi 8 kelompok masing-masing 5 ekor tikus. Ekstrak kunyit $100 \mathrm{mg} / \mathrm{kg} \mathrm{BB}$, ekstrak meniran $200 \mathrm{mg} / \mathrm{kg} \mathrm{BB}$ dan kombinasi IIII dengan perbandingan ekstrak kunyit dan meniran 75:50; 50:100; dan 25:150 $\mathrm{mg} / \mathrm{kg} \quad \mathrm{BB}$, sebagai pembanding digunakan aquades (normal), CMC Na 0,5\%, dan silimarin $100 \mathrm{mg} / \mathrm{kg}$ BB semua sediaan uji diberikan selama 7 hari secara peroral. Parasetamol dosis tunggal 2,5 $\mathrm{g} / \mathrm{kg} \quad \mathrm{BB}$ digunakan sebagai induksi hepatotoksin, diberikan pada hari ke-7. Aktivitas hepatoprotektif dianalisis dengan melihat gambaran hitpatologi liver.

\section{HASIL dan PEMBAHASAN}

Rendemen ekstrak kunyit sebesar $5,49 \%$, setalah dihilangkan minyak atsiri kunyit sebesar 0,78\%. Ekstrak meniran hasil maserasi dengan rendemen 9,68\%. Kadar air ekstrak kunyit dan meniran diperoleh hasil $5 \%$. Penetapan kadar abu total dan tidak larut asam ekstrak kunyit masing-masing 2,8\% dan 0,84\%, kadar abu total dan tidak larut asam ekstrak meniran masing-masing $7,44 \%$ dan 0,84 $\%$.

Penetapan profil KLT dalam ekstrak kunyit diperoleh tiga spot yang sejajar dengan spot standar kurkuminoid. Dari hasil yang didapat pada ekstrak meniran diperoleh dua macam spot dengan satu spot yang sejajar dengan spot standar (quercetin). Analisis kuantitatif ekstrak kunyit diperoleh kadar kadar kurkumin sebesar 30,34 \% b/b. Kadar total flavonoid dalam ekstrak meniran

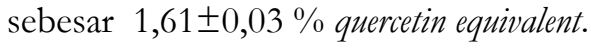

Analisis histopatologi dengan menggunakan organ liver dilakukan untuk mengetahui gambaran jaringan pada liver terkait munculnya kerusakan liver yang diakibatkan oleh induksi parasetamol. Dalam analisis histopatologi ini digunakan pengecatan dengan menggunakan hematoksilin dan eosin. Hasil selengkapnya dapat dilihat dalam Tabel I dan Gambar 1. 
Tabel I. Analisis dan intrepretasi gambaran histopatologi organ liver

\begin{tabular}{lcccc}
\hline \multirow{2}{*}{ Kelompok } & Dosis $(\mathbf{m g} / \mathbf{k g ~ B B})$ & \multicolumn{3}{c}{ Intrepretasi } \\
\cline { 3 - 5 } & & MFNPD & MFDM & $\begin{array}{c}\text { Atrofi } \\
\text { hepatosit }\end{array}$ \\
\hline Normal & - & TAP & TAP & TAP \\
\hline Parasetamol & $2,5 \mathrm{~g} / \mathrm{kg}$ & +++ & + & + \\
\hline Silimarin & 100 & TAP & + & TAP \\
\hline Kunyit & 100 & ++ & ++ & + \\
\hline Meniran & 200 & + & + & + \\
\hline Kombinasi I & kunyit : meniran $=75: 50$ & TAP & + & TAP \\
\hline Kombinasi II & kunyit : meniran $=50: 100$ & ++ & ++ & TAP \\
\hline Kombinasi III & kunyit : meniran $=25: 150$ & ++ & ++ & TAP \\
\hline
\end{tabular}

Ket: MFNPD $=$ Multifokal Nekrosis disekitar Pembuluh Darah, MFDM= Multifokal Degenerasi Melemak, TAP $=$ Tidak Ada Perubahan, $(+)$ lemah, $(++)$ sedang, $(+++)$ kuat,

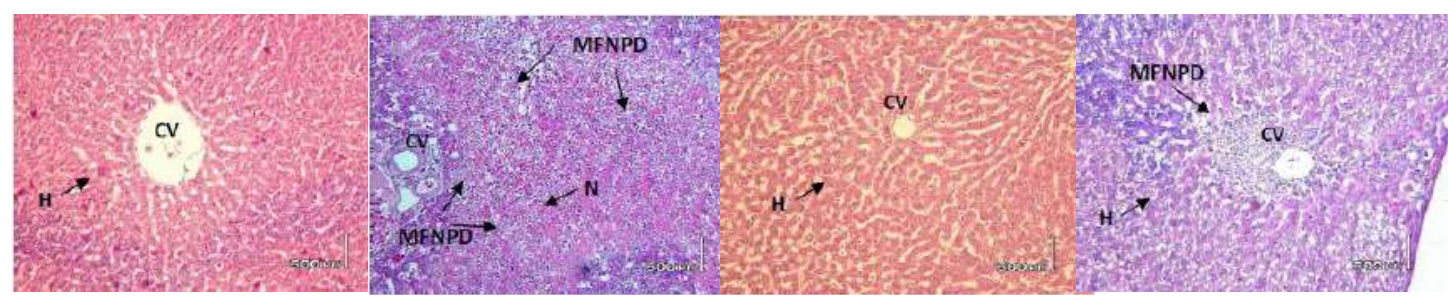
A
B
C
D

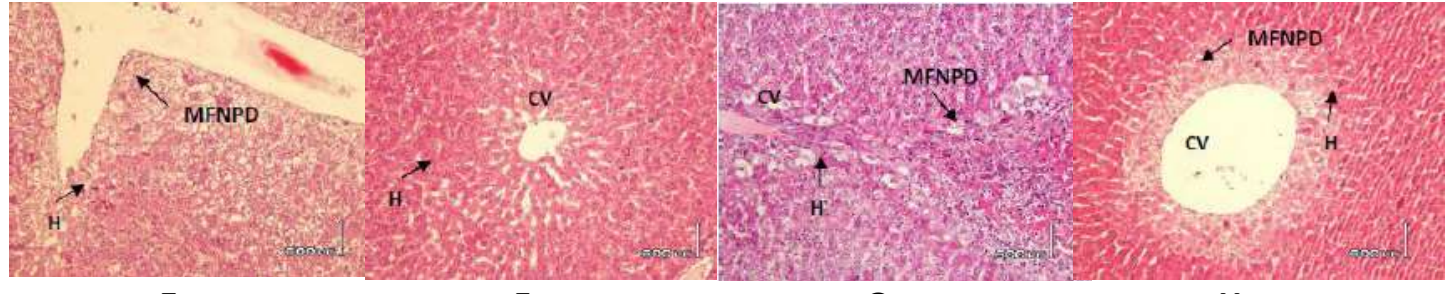

E

G

H

Gambar 1. Histopatologi liver pengecatan HE pengamatan dengan perbesaran $200 \mathrm{x}$. (a) normal, (b) parasetamol, (c) silimarin, (d) kunyit, (e) meniran, (f) kombinasi I, (g) kombinasi II, (h) kombinasi III. Ket $\mathrm{CV}=$ central vena, $\mathrm{H}=$ Hepatosit, $\mathrm{N}=$ Neutrofil MFNPD=Multifokal Nekrosis disekitar Pembuluh Darah.

Dari hasil analisa histopatologi pada Tabel I dan Gambar 1 diperoleh gambaran kelompok normal tanpa perlakuan induksi perasetamol terlihat gambaran liver dengan hepatosit nomal, tidak menunjukkan adanya perubahan yang berarti pada hepatosit. 

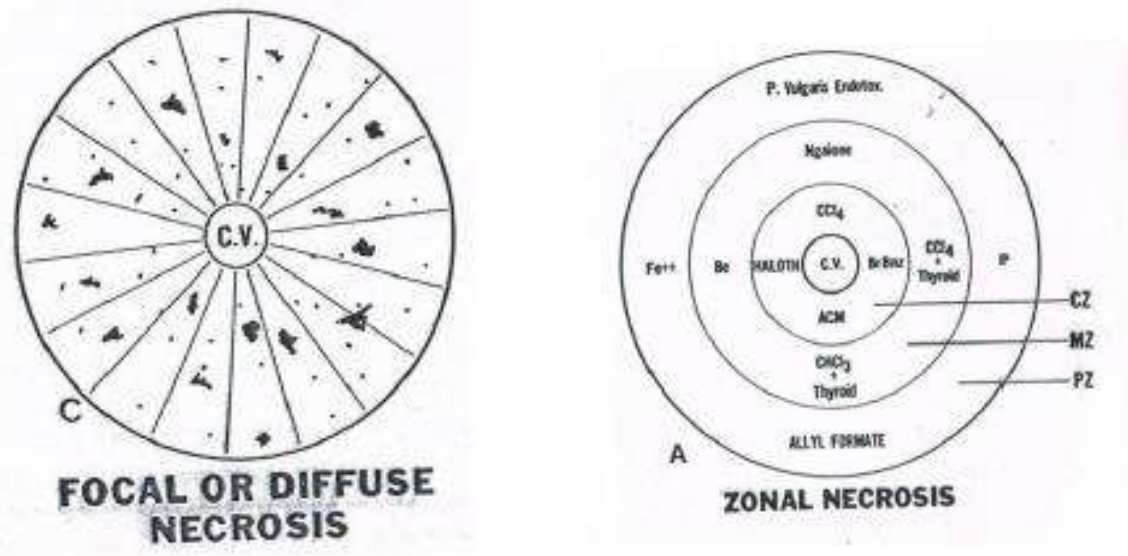

Gambar 2. Nekrosis fokal dan nekrosis zonal (Zimmerman, 1978)

Berbeda dengan kelompok normal, kelompok induksi parasetamol menunjukkan adanya perubahan yang signifikan pada liver. Terlihat adanya nekrosis dengan tipe multifokal nekrosis sekitar pembuluah darah. Terjadinya nekrosis ini ditandai dengan adanya kematian sel (kariopiknotik, kariolisis, sitoplasma hipereosinofilik) pada beberapa lokasi di sekitar pembuluh darah. Dari gambaran liver juga terlihat jumlah neutrofil dan leukosit yang menunjukkan adanya peradangan pada liver. Nekrosis sel hati fokal merupakan nekrosis yang terjadi secara acak pada satu sel atau sekelompok kecil sel pada seluruh daerah lobulus-lobulus hati (Zimmerman, 1978).

Kerusakan liver akibat induksi parasetamol dengan tipe fokal sama seperti penelitian yang dilakukan oleh Tabassum et al., (2005) dengan distribusi lebih dari $67 \%$. Hasil ini sedikit berbeda dengan karakter yang muncul pada beberapa induksi parasetamol, Parasetamol memberikan kerusakan tipe nekrosis zonal (Gambar 2). Nekrosis zonal sel hati adalah nekrosis sel hati yang terjadi pada daerah yang identik di semua lobulus hati. Penyebabnya berbeda-beda sesuai zona yang terkena. Nekrosis centrizonal (CZ) yang mengenai sel-sel disekeliling vena hepatika sentral (Zimmerman, 1978; Bigoniya et al., 2009). Selain ditemukan gambaran nekrosis fokal pada kelompok induksi, juga ditemukan gambaran atropi hepatosit yang ditandai dengan ukuran hepatosit lebih kecil dan sitoplasma tampak melebar.

Silimarin sebagai kontrol positif mampu memberikan gambaran aksi hepatoprotektif yang ditunjukkan gambaran histopatologi liver. Dalam kelompok ini tidak terlihat gambaran multifokal nekrosis pada daerah pembuluh darah, melainkan terlihat adanya gambaran multifokal degenerasi melemak. Terjadinya degenerasi melemak dapat terjadi sebagai akibat induksi parasetamol yang memicu lipid peroksidase. Terjadinya degenerasi melemak ini masih bersifat reversible sehingga hepatosit yang terlihat masih bersifat normal, tidak muncul nekrosis.

Pemberian ekstrak dalam bentuk tunggal baik itu kunyit maupun meniran terlihat adanya perubahan histopatologi liver. Pemberian ekstrak kunyit dengan dosis $100 \mathrm{mg} / \mathrm{kg}$ bb masih terlihat adanya multifokal nekrosis pada bagian pembuluh darah dengan tingkat keparahan sedang $(++)$. Penelitian yang dilakukan oleh Somchit et al., (2005) pemberian ekstrak kunyit tidak menunjukkan adanya perubahan histpatologi pada liver. Perbedaan hasil penelitian terjadi karena induksi parasetamol yang digunakan dalam penelitian Somchit et al., (2005) menggunakan parasetamol dengan dosis lebih kecil yaitu 600 mg.kg BB. 
Pemberian ekstrak meniran dalam bentuk tunggal dengan dosis 200 $\mathrm{mg} / \mathrm{kg} \quad \mathrm{BB} \quad$ memberikan hasil histopatologi pada liver lebih baik dibandingkan dengan ekstrak meniran dosis tunggal. Terlihat adanya multifokal nekrosis pada daerah pembuluh darah tingkat keparahan lemah $(+)$. Sama seperti ekstrak kunyit, beberapa bagian terlihat adanya perubahan hepatosit yang ditandai dengan multifokal degenerasi melemak. Hal yang sama penelitian yang dilakukan oleh Tabassum et al.,(2005) pemberian ekstrak meniran mampu meregenerasi nekrosis pada liver.

Pemberian kombinasi ekstrak kunyit dan meniran memberikan gambaran histopatologi yang lebih baik dibandingkan dalam bentuk tunggalnya. Kelompok kombinasi I yaitu ekstrak kunyit $75 \mathrm{mg} / \mathrm{kg}$ BB dan meniran 50 $\mathrm{mg} / \mathrm{kg}$ BB mulai menunjukkan adanya perbaikan secara histopatologi jika dibandingkan dengan kelompok induksi parasetamol. Pada kelompok ini tidak ada perubahan signifikan pada sel hepatosit, tidak terlihat nekrosis, terlihat multifokal degenerasi melemak.

Kombinasi II ekstrak kunyit 50 $\mathrm{mg} / \mathrm{kg}$ BB dan meniran $100 \mathrm{mg} / \mathrm{kg} \mathrm{BB}$, terlihat adanya gambaran perubahan histopatologi multifokal nekrosis pada pembuluh darah dengan tingkat kerusakan yang sedang $(++)$ bila dibandingkan dengan kelompok induksi parasetamol. Kelompok kombinasi III ekstrak kunyit $25 \mathrm{mg} / \mathrm{kg} \mathrm{BB}$ dan meniran $150 \mathrm{mg} / \mathrm{kg}$ $\mathrm{BB}$, terlihat adanya multifokal nekrosis pada daerah pembuluh darah dengan tingkat kerusakan lemah $(+)$ sampai sedang $(++)$.

Dalam penelitian yang dilakukan oleh Singh et al (2013), pemberian kurkumin mampu meningkatkan viabilitas hepatosit, menurunkan jumlah terbentuknya malondialdehide (MDA), dan meningkatkan aktivitas Calcium ATPase. Kurkumin sebagai antioksidan alami mampu meningkatkan jumlah glutathione dan meningkatkan aktivitas superoxide dismutase (SOD), glutathione peroxidase (GPx), glutathione reductase (GR), glutathione $S$ transferase (GST), dan catalase (CAT) (Farghaly \& Hussein, 2010). Ekstrak meniran diidentifikasi keberadaan senyawa flavonoid (quercetin). Telah diketahui bahwa kandungan flavonoid dalam ekstrak meniran memiliki aktivitas antioksidan. Quercetin mampu meningkatkan aktivitas glutathione peroxidase dan glutathione reductase pada hewan uji yang diinduksi parasetamol (Guzy et al., 2004). Dalam penelitian yang telah dilakukan oleh Novianto (2013) kombinasi kunyit dan meniran mampu menurunkan parameter kadar SGPT, SGOT, ALP, Bilirubin dan menaikkan kadar total protein serta mampu menaikkan kadar glutathione, katalase dan menurunkan kadar lipid peroksida pada hewan uji yang diinduksi parasetamol.

\section{KESIMPULAN}

Hasil penelitian menunjukkan bahwa kombinasi I yaitu ekstrak kunyit dan meniran dosis 75 dan $50 \mathrm{mg} / \mathrm{kg} \mathrm{BB}$ mampu memberikan aktivitas hepatoprotektif yang optimal. Kombinasi ini mampu mencegah terjadinya multifokal nekrosis disekitar pembuluh darah.

\section{DAFTAR PUSTAKA}

Bigoniya, P., Singh, C.S., and Shukla, A. 2009, A Comprehensive Review of Different Liver Toxicants used in Experimental Pharmacology, IJPSDR, 1(3): 124-135

Chang C.-C., Yang M.-H., Wen H.-M. and Chern J.-C.,2002,Estimation of total flavonoid content in propolis by two complementary colorimetric methods; J. Food Drug Analysis, 10, 178-182.

Clark, R., Fisher, J.E., Sketris, I.S., and Johnston, G.M. 2012, Population prevalence of high dose paracetamolin dispensed paracetamol/opioid prescriptioncombinations: an 
observational study, $B M C$ Pharmacology and Toxicology, I:1-8.

Depkes RI, 2008, Farmakope Herbal

Indonesia, Jakarta.

Devaraj, V.C., Krishna, B.G., Viswanatha, G.L., Kamath, J.V., and Kumar, S. 2011, Hepatoprotective activity of Hepax-A polyherbal formulation, APJTB,1:142-146

Donatus IA, Sardjoko, and Vermeulen NP.1990, Cytotoxic and cytoprotective activities of kurkumin.Effects on parasetamol-induced cytotoxicity, lipid peroxidation and glutathione depletion in rat hepatocytes.Biochem Pharmacol, 39:1869-1875.

Farghaly, H., and Hussein, M. 2010, Protective Effect of Kurkumin Against Paracetamol-induced Liver Damage, Aust. J. Basic \& Appl. Sci., 4(9): 4266-4274, 2010.

Goenarwo, E., Chodijah., Alimi, M.S. 2009, Pengaruh Air Perasan Kunyit terhadap Kadar Serum Glutamic Oxaloacetic Transaminase (SGOT), Serum Glutamic Pyruvic Transaminase (SGPT), dan Bilirubin Total Serum, Sains Medika Jurnal Kedokteran dan Kesehatan), 1 (1):16-23.

Guzy, J., Zuzana Chovanová, Z., Mareková, M., Zenóbia Chavková, Z., Tomeèková, V., Mojizová, G., \& Jaroslav Kusnír, J. 2004, Efect of quercetin on paracetamolinduced rat liver mitochondria dysfunction, Biologia, Bratislava, 59 (3): $399 \mid 403$.

Harish and Shivanandappa, 2006, Antioxidant activity and hepatoprotective potential of Phyllanthus niruri, Food Chemistry, 95(2):180-185.

Hinson, J.A., Roberts, D.W., and James, L.P. 2010, Mechanisms of Acetaminophen-Induced Liver
Necrosis, Handb Exp

Pharmacol.196: 369-405.

Kim, YW, Kang HE, Lee MG, Hwang SJ, Kim, SC, Lee, CH, 2009, Liquiritigenin, a flavonoid aglycone from licorice, has choleretic effect and the ability to induce hepatic transporters and phase II enzyme, $A m J$ Physiol Gastrointest Liver Physiol, 296:G372-G381.

Kiso Y, Suzuki Y, Watanabe N. 1983, Antihepatotoxic principles of Curcuma longa rhizomes. Planta Med, 49:185-187.

Manjrekar, A.P., Jisha, V., Bag, P.P., Adhikary, B., Pai, M.M., Hegde, A., and Nandini, M. 2008, Effect of Phyllanthus niruri Linn treatment on Liver Kideny and tests in $\mathrm{CCl}_{4}$ induced hepatotoxic rats, Indian Journal of Experimental Biology, 46:514-520.

Park EJ, Jeon CH, Ko G., 2000. Protective effect of kurkumin in rat liver injury induced by carbon tetrachloride.Journal Pharm Pharmacol;52:437-440.

Pothitirat, W. and Gritsanapan, W. 2005, Quantitative Analysis of Kurkumin,

Demethoxykurkumin and Bisdemethoxykurkumin in the Crude Kurkuminoid Extract from Curcuma longa in Thailand by TLC Densitometry, Mahidol University Journal of Pharmaceutical Sciences, 32(1-2): 23-30

Rajagopalan, R., Baskaran, M., and Periyasamy, L.2010, Effect of Phyllanthus niruri on Alcohol and Polyunsaturated Fatty Acid Induced Oxidative Stress in Liver, Int I Pharm Pharm Sci, 2(4): 5862.

Sabate, M., Ibanez, L., Perez, E., Vidal, X., Buti, M., and Xiol, X., et al. 2011, Paracetamol in therapeutic dosages and acute liver injury: causality assessment in a prospective case series, BMC Gastroenterology, I:1-7. 
Said, O., Khalil, K, Fulder S. 2002. Ethnobotanical survey of medicinal herbs of the middle eastern region.Journal of Ethnopharmacology, 83: 251-265.

Salama, S.M., Abdulla, M.A., AlRashdi, A.S., Ismail, S., Alkiyumi, S.S., and Golbabapour, S. 2013, Hepatoprotective effect of etanolic extract of Curcuma longa on thioacetamide induced livercirrhosis in rats, $B M C$ Complementary and Alternative Medicine, 13(56):1-17.

Setty, S. R., Quereshi, A.A., Swamy, A.H.M.V., Patil, T., Prakash, T., Prabhu, K., and Gouda, A.V.. 2007, Hepatoprotective activity of Calotropis procera flowers against parasetamol-induced hepatic injury in rats, Fitoterapia,78:451-454.

Singh, D. and Gupta, R.S. 2011,Hepatoprotective Activity of Metanol Extract of Tecomella undulate against Alcohol and Parasetamol Induced Hepatotoxicity in Rats, Life
Sciences and Medicine Research, 26:1-8.

Somchit, M.N., Zuraini, A., Bustaman, A.A., Somchit, N., Sulaiman, N,R., and Norantulina, R. 2005, Protective Activity of Turmeric (Curcuma longa) in Parasetamol Induced Hepatotoxicity in Rats, International Journal of Pharmacology,1 (3); 252-256.

Suhad, S. Humadi., and Istudor, V. 2008, Quantitative Analysis Of BioActive Compound In Hibiscus sabdariffa L. Extracts. Note I Quantitative Analysis Of Flavonoids, Farmacia, 56 (()).

Tabassum, N., Agrawal, and Shyam. S., 2004, .Hepatoprotective Activity Of Eclipta alba Hassk. Against Parasetamol Induced Hepatocellular Damage In Mice, JK - Practitioner,11(4):278280.

Zimmerman, H.J. 1978, Hepatotoxicity, Appleton Century Crofts, New York. 